\title{
Sistem Pendidikan Umum Pada Masa Orde Baru (1968-1998)
}

\author{
Safei, Hudaidah \\ Universitas Sriwijaya \\ menisafei973@gmail.com \\ hudaidah@fkip.unsri.ac.id
}

\begin{abstract}
Abstrak
Pendidikan adalah pilar utama berdirinya suatu bangsa, Pendidikan merupakan usaha untuk merancang masa depan manusia sebagai generasi yang memajukan sebuah bangsa, seiring berjalannya waktu konsep pendidikan tidak terlepas dari kebijakan pemerintah, suatu perubahan terjadi dari masa ke masa bahkan meningkat dalam hal kualitasnya namun didalam peningkatanya itu terdapat juga kekurangan yang perlu segera diatasi Orde Baru dimulai dari 1968 sampai 1998 pada pemerintahanya dikepalai oleh Jenderal TNI H. M. Soeharto seabagai presiden terpusat. Kebijakan Pendidikan pada masa Orde Baru adalah terpusat atau disebut juga sentralisasi. Pelaksanaan pendidikan di era Orde Baru dialih fungsikan sebagai instrumen pembangunan ekonomi nasional dalam penyelenggaraan nya pendidikan diselenggarakan secara otorita kekuasaan administratif birokratis. Penyeragaman kurikulum diikuti dengan penyeragaman metode mengajar dan sistem evaluasi. Fokus kajian ini pada sistem pendidikan masa Orde Baru, sistem pendidikan umum masa orde baru, kelebihan pendidikan masa Orde Baru serta kekurangan pendidikan masa orde baru. Kajian ini menggunakan pendekatan kualitatif dengan metode studi historis. Pada masa Orde Baru ini sistem mengalami kemajuan terutama di sekolah dasar, tenaga pengajar kualitasnya sangat buruk tapi jumlah pengajarnya mengalami peningkatan dan terus menerus diluluskan sehingga kualitasnya sangat kurang sesuai dengan yang diharapkan.
\end{abstract}

Kata Kunci: Sistem Pendidikan, Orde Baru

\begin{abstract}
Education is the main pillar of the founding of a nation, education is an effort to design the future of humans as a generation thet advances a nation, over time the concept of aducation is inseparable from goverment policy, a chage occurs from time to time and even increases in quality but in it's improvement there are also ahortcomings that need to be addressed immetiately. The new orde started from 1968 to 1998 when the goverment was headed by TNI H. M. Soeharto as the entralized president. Education policy during the new orde era was centralized or also called centralization. The implementation of education in the new orde era was transferred to it's function as an instrument of national economic development in that education was carried out under the authority of bureaucratic administrative power. Uniformity of teaching methods and evaluation system. The focus of this study is on the education system during the new orde era, the advantages of education during the orde era and lack of education during the new orde. This study uses a qualitative with history study methods. . During the new orde era, the system experienced progress, especially in elementary schools, the quality of the teaching staff was very poor, but the number of teachers had increased and were continuously graduarted so that the quality was not as expected.
\end{abstract}

Keywoards: Education System, New Orde 


\section{Pendahuluan}

Sesudah PKI berhasil ditumpaskan, pemerintahan Orde Baru yang dikepalai oleh Presiden Suharto terus mengadakan pembaruan serta pembangunan di seluruh bidang termasuk pendidikan. Ketetapan MPRS Nomor: XXVII/Tap/MPRS/1966 yang berisi tujuan pendidikan merupakan untuk melahirkan manusia Pancasila sejati bersumber pada ketentuan-ketentuan yang dikehendaki dalam pembukaan Undang- Undang Dasar 1945, sehingga dipikirkan usaha-usaha pembaharuan pendidikan. Semenjak tahun 1959, Indonesia terletak di dasar gelora manipol (manifesto Politik) USDEK (UUD 1945, Sosialisme Indonesia, Demokrasi Terpimpin, Ekonomi Terpimpin, serta Karakter Indonesia). Manipol-Usdek sebagai "dewa" dalam kehidupan politik serta seluruh bidang kehidupan termasuk di dalam bidang pendidikan. Keputusan Presiden Nomor 145 tahun 1965, tujuan nasional pendidikan era Orde Lama cocok dengan manipol-USDEK. Tujuan pendidikan yang diterapkan ialah Panca Wardana (5 pokok perkembangan). Tujuan pendidikan ini tidak berlangsung lama serta ditinggalkan sesudah meletusnya kejadian Gram 30/S/PKI pada tahun 1965 (Abdullah, 2011).

Masyarakat mulai sadar bahwa terdapat maksud politik PKI yang tercantum dalam tujuan pendidikan tersebut dengan menggunakan Pancasila selaku tamengnya. Dikeluarkannya ketetapan MPRS Nomor: XXVII tahun 1966 menghapus Keputusan Presiden No 145 tahun 1965 serta Penetapan Presiden No 19 tahun 1965 tentang pokok sistem pendidikan nasional Pancasila dinyatakan tidak berlaku lagi. Pada akhir 1965 penumpasan PKI sukses dilakukan oleh ABRI dengan rakyat, akan tetapi politik PKI belum lenyap disebabkan tidak dibubarkan oleh pemerintah (Presiden). Rasa tidak puas dari masyarakat atas kurang tegasnya Presiden Sukarno hingga terjalin demonstrasi berkelanjutan menuntut tritura yang isinya merupakan pelarangan politik PKI di Indonesia yang berdampak pengeluaran Supersemar 11 Maret 1966. Pada tahun 1966 terjadi dualisme kepemimpinan antara Suharto serta Sukarno. Keluarnya TAP MPR Nomor: XIII/MPRS/1966 pada 25 Juli 1966 yang mengangkut Suharto buat membentuk kabinet baru, sebaliknya presiden memegang kekuasaan pemerintahan serta kepala negeri. Sukarno selaku kepala negeri serta Suharto selaku kepala negeri yang berjalan rusuh, MPRS melaksanakan persidangan istimewa bertepatan pada 7-12 Maret 1967 yang menghasilkan Ketetapan Nomor: XXXIII/MPRS/1967 tentang pencabutan kekuasaan negeri serta 
pemerintahan Presiden Sukarno dan mengangkut Suharto selaku presiden (Syaharuddin dan Susanto, 2019; Zuhdi, dkk., 2018).

Pendidikan merupakan salah satu kebutuhan manusia untuk bisa berproses dan berinteraksi didunia luar dengan semua masyarakat sekitarnya. Pendidikan juga menjadi salah satu bekal terpenting masa depan (Nizar, 2009). Pendidikan itu sudah kita kenal sejak zaman sebelum Negara indonesia merdeka hingga saat ini. Pendidikan menjadi salah satu hal pokok yang harus diperhatikan karena pendidikan mampu membentuk karakter pribadi setiap orang apabila sungguh-sungguh dalam menekuninya. Pendidikan adalah proses pembelajaran tentang akhlak, ilmu pengetahuan dan keterampilan yang menjadi kebiasaan turun-temurun sekelompok orang untuk melakukan pengajaran, pengamatan, pelatihan atau penelitian (Suharto, 2005). Menurut Undang-Undang Republik Indonesia No, 20 Tahun 2003 tentang sistem Pendidikan Nasional Pasal 1 ayat (1), pengertian pendidikan adalah usaha sadar dan terencana untuk mewujudkan suasana belajar dan proses pembelajaran agar peserta didik secara aktif mengembangkan potensi dirinya untuk memiliki kekuatan spiritual keagamaan, pengendalian diri, kepribadian, kecerdasan, akhlak mulia, serta keterampilan yang diperlukan dirinya, masyarakat, bangsa dan Negara (https://kelembagaan.ridtekdkti.go.id).

Secara langsung maupun tidak langsung pendidikan mampu memberikan kita ilmu pengetahuan baru, membentuk karakter pribadi yang lebih baik dan mempermudah kita merintis karir dimasa mendatang. Pendidikan menurut salah satu tokoh yaitu M. J. Langeveld (1980), merupakan upaya yang dilakukan secara sengaja oleh seseorang yang dewasa untuk mencapai kedewasaan seseorang terutama anak-anak yang masih belum dewasa (https://www.academia.edu). Sejarah pendidikan mencatat bahwa indonesia merupakan salah satu negara yang memiliki kualitas pendidikan paling rendah dibandingkan negara-negara lainnya, meskipun usaha pemerataan sistem pendidikan sudah dilakukan dan dianggap meningkat cukup signifikan (CNN Indonesia). Pendidikan saat ini secara umum mungkin sudah dilakukan hampir keseluruh wilayah Indonesia. Sistem pendidikan yang dilakukan pun hampir keseluruhan menggunakan teknologi-teknologi canggih seperti komputer/laptop, LCD proyektor, handphone, WIFI, dan sebagainya.

Orde Baru berlangsung dari tahun 1968 sampai 1998, serta bisa dikatakan sebagai masa pembangunan nasional. Dalam bidang pembangunan pendidikan, spesialnya pendidikan dasar, terjadi suatu loncatan yang sangat signifikan dengan terdapatnya 
Instruksi Presiden (Inpres) Pendidikan Dasar. Tetapi, yang disayangkan ialah pengaplikasian inpres ini hanya berlangsung dari segi kuantitas tanpa diimbangi dengan pertumbuhan mutu. Yang terpenting pada masa ini ialah menghasilkan lulusan terdidik sebanyak- banyaknya tanpa mencermati mutu pengajaran serta hasil didikan. Pada masa Orde Baru, kurikulum senantiasa hadapi pergantian nyaris masing-masing dekade seperti kurikulum 1968, 1975, 1984 serta terakhir kurikulum 1994. Pasti saja dari pergantian kurikulum tersebut ada pula pergantian tujuan dari sesuatu pembelajaran serta sistem pendidikannya, Orde Baru tidak semacam Orde Lama, Secara universal pendidikan Orde Lama sebagai bentuk interpretasi pasca kemerdekaan di dasar kendali kekuasaan Soekarno cukup memberikan ruang leluasa terhadap pendidikan.

Pemerintahan yang berasaskan sosialisme jadi referensi dasar gimana pendidikan hendak dibangun serta dijalankan demi pembangunan serta kemajuan bangsa Indonesia di masa mendatang sebaliknya pendidikan pada masa Orde Baru pemerintahanya dipandu oleh soeharto Orde Baru identik dengan pandangan hidup ataupun slogan pembangunan. Begitu pula arah serta kebijakan pendidikan disesuaikan dengan gerakan pembangunan. Kata pembangunan didahulukan saat sebelum Pancasila. Ini menunjukkan bahwasanya pembangunan meski tidak secara formal dijadikan pandangan hidup, tetapi jadi pijakan dasar Orde Baru dalam memusatkan jalannya pemerintahan serta pendidikan tidak hanya Pancasila. Kurikulum 1984 mengusung "process skill approach" ialah proses jadi lebih berarti dalam penerapan pendidikan, tetapi tujuan senantiasa aspek berarti. Kedudukan siswa dalam kurikulum ini jadi mengamati suatu, mengelompokkan, mendiskusikan, sampai memberi tahu. Model ini diucap Metode Belajar Siswa Aktif (CBSA) ataupun Student Active Leaming (SAL), (https://attriolong.com).

Tujuan Penelitian ini difokuskan bagaimana perkembangan sistem pendidikan pada masa Orde Baru dan bagaimana pula sistem yang diterapkannya. Penelitian yang relevan dengan kajian ini antara lain, penelitian tentang "Sistem Pendidikan Indonesia Pada Masa Orde Lama (Periode 1945-1966)" (Fadli, \& Kumalasari, 2019). Penelitian Jailani, \& Muhammad (2019) tentang “Kilas Balik Kebijakan Pendidikan Islam Indonesia pada Masa Orde Baru (1967-1997)”. Penelitian Malla, (2011) tentang “Kajian Sosio Historis Tentang Politik Kebijakan Pendidikan Islam di Indonesia". Penelitian tentang "Pengaruh Zeitgeist Terhadap Muatan Sejarah di Buku Teks Pelajaran Sejarah SMA Kurikulum 1975-2004” (Marlina, (2016). Penelitian Yuningsih, (2015) tentang “Kebijakan Pendidikan Islam Masa 
Orde Baru". Dengan demikian penelitian ini memiliki urgensi bahwa perkembangan pendidikan sejak masa Orde Lama sampai dengan masa Orde Baru dapat menjadi catatan penting dalam merumuskan kebijakan pendidikan di Indonesia. Hal ini dapat dijadikan tolak ukur dalam mendesain kurikulum pendidikan di Indonesia yang berkualitas.

\section{Metode Penelitian}

Metode yang digunakan dalam penelitian ini yaitu, metode sejarah (Sjamsudin, 2012). Metode sejarah dapat dikatakan suatu proses mengkaji, menganalisa dan membaca secara kritis redaksional buku teks dan mengaitkan dengan kondisi masyarakat pada tahun berlangsungnya kurikulum 1975. Penggunaan metode historis dalam penulisan artikel ini dilakukan melalui 4 tahap penelitian, yaitu: (1) Heuristik, menghimpun bahan-bahan atau sumber melalui studi kepustakaan, (2) Kritik sumber, menyeleksi data-data yang telah terkumpul melalui kritik intern dan kritik ekstern, (3) Interpretasi (4) Historiografi. Topik dalam pembuatan artikel ini sudah ditentukan oleh ibu/bapak dosen mata kuliah "sejarah pendidikan" sedangkan sistematika berikutnya mulai dari pembuatan judul, abstrak, inti, pendahuluan hingga pembahasan menggunakan literatur baca mulai dari e-book, jurnal, artikel, makalah, laporan penelitian terdahulu, karya ilmiah, ensiklopedia, internet, dan sumber-sumber lainnya. Dalam pembuatan artikel juga terdapat sistem mengumpulkan informasi yang terpecaya (relevan) dengan topik yang sudah ditentukan dari pembahasan sebelumnya.

\section{Pembahasan}

Perubahan pendidikan dari masa ke masa mengalami peningktan yang sangat baik pada Orde Baru juga perubahan itu terlihat mulai dari perubahan kurikulumnya, sistem pendidikannya dan bahkan untuk menentukan kelulusanya pun berubah bukan berdasarkan nilai Ujian Nasional bahkan pada masa Orde Baru ini pemerintah mewajibkan anak-anak berusia 7-12 tahun untuk mengenyam pendidikan Sekolah Dasar biasa disebut sebagai wajib belajar 6 tahun. Di samping itu ada dampak negatifnya juga pada pendidikan Orde Baru ini dikarenakan sistem pemerintahanya otoriter sehingga paham Orde Baru yang membuat kita khawatir buat melangkah lebih maju.

Dengan demikian, pendidikan pada masa Orde Baru bukan untuk tingkatkan taraf kehidupan rakyat, terlebih buat tingkatkan sumber energi manusia Indonesia, namun malah 
mengutamakan orientasi politik supaya seluruh rakyat itu senantiasa patuh pada tiap kebijakan pemerintah. Jika putusan pemerintah merupakan putusan yang adil dan tidak boleh dilanggar. Seperti itu doktrin Orde Baru pada sistem pendidikan kita. Indoktrinisasi pada masa kekuasaan Soeharto ditanamkan dari jenjang sekolah dasar hingga pada tingkatan pendidikan tinggi, pendidikan yang sepatutnya memiliki kebebasan dalam pemikiran. Pada masa itu, pendidikan difokuskan pada pengembangan militerisme yang militan sesuai dengan tuntutan kehidupan suasana perang dingin. Seluruhnya serba kaku serta berjalan dalam sistem yang otoriter.

Secara umum tujuan pendidikan sudah ditanyakan dalam Undang-Undang Dasar 1945 Bab XII pasal 31: a). Masing- masing penduduk negeri berhak mendapat pengajaran; b). Pemerintah mengusahakan serta menyelenggarakan satu sistem pengajaran nasional, yang diatur dengan undang-undang. Perihal tersebut kemudian dikuatkan dalam pasal 4 ketetapan MPRS Nomor XXII/MPRS/1966 tersebut, berikutnya disebutkan tentang isi pendidikan wajib memuat: a). Mempertinggi mental, moral, budi pekerti, serta menguatkan kepercayaan beragama; b). Mempertinggi kecerdasan serta keahlian; c). Membina/mengebankan fisik yang kuat serta sehat.

Ketetapan MPRS di atas jadi indikator berubahnya pendidikan nasional dari Orde Lama mengarah ke Orde Baru. Itu sangat kentara. Paling tidak, ada 2 perihal, yakni pembentukan manusia secara pancasilais sejati yang berhubungan oleh kejadian tragis pasca Gerakan 30 September ataupun 1 Oktober, kala Orde Baru menuduh PKI selaku pengkhianat Pancasila sebab ingin mengganti Dasar Negera Pancasila menjadi komunis. Setelah itu yang kedua merupakan mengganti mental penduduk yang penuh doktrindoktrin Manipol USDEK, yang merupakan kebijakan Soekarno.

Jadi, Orde Baru berupaya mengenali dirinya dengan jalur memutus pengaruh PKI serta Soekarno, tercantum dalam perihal ini bidang pendidikan. Berikutnya, TAP MPRS tersebut menyatakan supaya di perguruanperguruan besar diberikan kebebasan mimbar/ilmiah seluas- luasnya yang tidak menyimpang dari UUD 1945 serta falsafah negeri, Pancasila. Usaha pemerintah Orde Baru untuk memperluas peluang mendapatkan pendidikan dasar mulai terwujud pada 1973. Dengan uang yang ada, pemerintah waktu itu memakainya untuk memeratakan pembangunan pendidikan, antara lain lewat Inpres Nomor. 10 tahun 1973 tentang program dorongan pembangunan sekolah dasar. 
Berikutnya usaha yang sudah diawali pada tahun terakhir Pelita I ini setelah itu dilanjutkan pada Pelita II dengan lebih jelas, merumuskan ekspansi peluang belajar sekolah selaku salah satu prioritas pembangunan bidang pendidikan. Orde Baru menjalankan kebijakan pendidikan nasionalnya pada Pelita II. Mulai Pelita II pemerataan pendidikan dijadikan kebijakan pokok. Pada akhir Pelita II, lahirlah Instruksi Presiden untuk pembangunan fasilitas Sekolah Dasar. Semenjak saat itu, ribuan sekolah beserta sarana yang lain disediakan untuk membagikan peluang yang luas untuk anak yang berusia 7-12 tahun untuk mendapatkan pendidikan Sekolah Dasar presiden (Syaharuddin dan Susanto, 2019).

Tujuan umum Pendidikan Sekolah Dasar menjelaskan agar lulusan-lulusan: a). Mempunyai sifat- sifat dasar selaku masyarakat negeri yang baik; b). Sehat jasmani serta rohani; dan c). Mempunyai pengetahuan, keahlian serta perilaku dasar yang dibutuhkan untuk melanjutkan pelajaran, bekerja di penduduk, meningkatkan diri sesuai serta meningkatkan diri sesuai dengan asas pendidikan seumur hidup. Adapun tujuan khusus Pendidikan Sekolah Dasar dijelaskan di bawah ini.

A. Di bidang Pengetahuan:

1. Mempunyai pengetahuan dasar yang fungsional tentang.

2. Dasar-dasar kewarganegara serta pemerintah sesuai dengan Pancasila dan UndangUndang Dasar 1945.

3. Agama yang dianutnya.

4. Bahasa Indonesia dan penggunaanya selaku perlengkapan komunikasi.

5. Prinsip- prinsip dasar matematika.

6. Indikasi dan kejadian yang terjalin di sekitarnya.

7. Indikasi dan kejadian sosial, baik di masa lampau, ataupun di masa saat ini.

8. Mempunyai pengetahuan dasar tentang bermacam faktor kebudayaan tradisional.

9. Memili pengetahuan dasar tentang kesejahteraan keluarga, kependudukan, dan kesehatan.

10. Mempunyai pengetahuan dasar tentang bermacam bidang pekerjaan yang ada di masyarakat sekitarnya.

B. Di bidang Keahlian:

1. Memahami cara- cara belajar yang baik. 
2. Terampil memakai bahasa Indonesia.

3. Sanggup membongkar permasalahan simpel secara sistematis dengan menggunakan prinsip ilmu pengetahuan yang sudah diketahuinya.

4. Sanggup bekerja sama dengan orang lain serta berpartisipasi dalam kegiatankegiatan masyarakat.

5. Mempunyai keahlian olahraga.

6. Terampil sekurang- kurangnya dalam sesuatu cabang kesenian.

7. Memili keahlian dasar dalam segi kesejahteraan keluarga serta usaha pembinaan kesehatan.

8. Memahami sekurang- kurangnya satu tipe keahlian spesial yang cocok dengan atensi kebutuhan lingkungannya, selaku bekal buat mencari nafkah.

C. Di bidang Nilai serta Perilaku:

1. Menerima serta melakukan Pancasila serta Undang- Undnag Dasar 1945.

2. Menerima serta melakukan ajaran agama serta keyakinan terhadap Tuhan YME yang dianutnya, dan menghormati ajaran agama serta keyakinan terhadap Tuhan YME yang dianut orang lain.

3. Menyayangi sesama manusia, bangsa dan lingkungan sekitarnya.

4. Mempunyai perilaku demokratis serta tenggang rasa.

5. Mempunyai rasa tanggung jawab.

6. Bisa menghargai kebudayaan dan tradisi nasional tercantum bahasa Indonesia

7. Yakin pada diri sendiri serta berlagak makarya.

8. Mempunyai atensi serta perilaku positif terhadap ilmu pengetahuan.

9. Mempunyai pemahaman hendak disiplin serta patuh pada peraturan yang berlaku, leluasa dan jujur.

10. Mempunyai inisiatif, energi kreatif, perilaku kritis, rasional dan obyektif dalam membongkar perkara.

11. Mempunyai perilaku hemat, serta produktif.

12. Mempunyai atensi dan perilaku positif serta konstruktif terhadap berolahraga dan hidup sehat 
13. Mengadapi tiap tipe pekerjaan serta prestasi kerja di warga tanpa memandang besar rendahnya nilai sosial- ekonomi masingmasing tipe pekerjaan tersebut serta berjiwa dedikasi kepada warga.

14. Mempunyai pemahaman menghargai waktu (Yusuf, 2018).

\section{Kurikulum Pada Masa Orde Baru}

A. Kurikulum 1968

Kurikulum 1968 menekankan pendekatan organisasi materi pelajaran: kelompok pembinaan Pancasila, pengetahuan dasar, dan kecakapan khusus. Muatan materi pelajaran bertabiat teoritis, tidak mengaitkan dengan kasus faktual di lapangan. Pada masa ini siswa hanya berfungsi sebagai individu yang masif, dengan hanya menghapal teori- teori yang ada, tanpa terdapat pengaplikasian dari teori tersebut. Aspek afektif serta psikomotorik tidak ditonjolkan pada kurikulum ini. Instan, kurikulum ini hanya menekankan pembuatan partisipan didik hanya dari segi intelektualnya saja (https://attriolong.com diakses).

B. Kurikulum 1975

Kurikulum 1975 menekankan pada tujuan, supaya pendidikan lebih efisien serta efektif berdasar $\mathrm{MBO}$ ( management by objective). Tata cara, materi, serta tujuan pengajaran dirinci dalam Prosedur Pengembangan Sistem Instruksional (PPSI), yang dikenal dengan sebutan“"satuan pelajaran”, ialah rencana pelajaran tiap satuan bahasan. Tiap satuan pelajaran dirinci jadi: tujuan instruksional universal (TIU), tujuan instruksional khusus( TIK), materi pelajaran, perlengkapan pelajaran, aktivitas belajar- mengajar, serta penilaian. Pada kurikulum ini kedudukan guru jadi lebih berarti, sebab tiap guru harus untuk membuat rincian tujuan yang mau dicapai sepanjang proses belajar- mengajar berlangsung. Masing- masing guru wajib perinci dalam perencanaan penerapan program belajar mengajar. Tiap tatap muka sudah di atur serta dijadwalkan sedari awal. Dengan kurikulum ini seluruh proses belajar mengajar jadi sistematis dan bertahap (https://attriolong.com).

C. Kurikulum 1984

Kurikulum 1984 mengusung“ process skill approach”. Proses jadi lebih berarti dalam penerapan pendidikan. Kedudukan siswa dalam kurikulum ini menjadi mengamati suatu, mengelompokkan, mendiskusikan, hingga memberi tahu. Model ini disebut Cara Belajar Siswa Aktif( CBSA) ataupun Student Active Leaming (SAL). CBSA memposisikan guru 
selaku fasilitator, sehingga wujud aktivitas ceramah tidak lagi ditemui dalam kurikulum ini. Pada kurikulum ini siswa diposisikan selaku subjek dalam proses belajar mengajar. Siswa pula diperankan dalam pembuatan sesuatu pengetahuan dengan diberi peluang untuk mengemukakan komentar, bertanya, serta mendiskusikan sesuatu (https://attriolong.com).

D. Kurikulum 1994

Kurikulum 1994 ialah hasil upaya untuk memadukan kurikulum- kurikulum tadinya, paling utama kurikulum 1975 dan 1984. Pada kurikulum ini wujud opresi kepada siswa mulai terjalin dengan beratnya beban belajar siswa, dari muatan nasional hingga muatan lokal. Materi muatan lokal disesuaikan dengan kebutuhan daerah masing- masing, misalnya bahasa daerah kesenian, keahlian daerah, dan lain- lain. Bermacam kepentingan kelompok- kelompok masyarakat pula menekan supaya isu- isu tertentu masuk dalam kurikulum. Kesimpulannya, Kurikulum 1994 menjelma jadi kurikulum luar biasa padat. banyaknya beban belajar siswa yang wajib mereka tuntaskan, serta mereka tidak mempunyai opsi untuk menerima ataupun menolak terhadap banyaknya beban belajar itu (https://attriolong.com).

\section{Penerapan Sisitem Pendidikan Indonesia Pada Masa Orde Baru}

Penerapan pendidikan pada masa Orde Baru faktanya banyak mendapatkan hambatan, dikarenkan pendidikan Orde Baru mengusung pandangan hidup "keseragaman" sehingga memampatkan kemajuan dalam bidang pendidikan. EBTANAS dan UMPTN adalah seleksi yang menjadi penyeragaman intelektualitas peserta didik. Pada pendidikan Orde Baru kesetaraan dalam pendidikan tidak bisa diciptakan sebab faktor dominatif serta submisif masih sangat kental dalam pola pendidikan Orde Baru. Pada saat itu, siswa diberikan beban materi pelajaran yang banyak dan berat tanpa memperhatikan keterbatasan alokasi kepentingan dengan faktor- faktor kurikulum yang lain untuk jadi peka terhadap lingkungan. Beberapa perihal negatif lain yang terbentuk pada masa ini antara lain yaitu, pertama, bahan- bahan pendidikan ditunjukan untuk jadi pekerja sehingga berimplikasi pada hilangnya eksistensi manusia yang hidup dengan ide pikirannya (tidak memanusiakan manusia). Kedua, lahirnya kalangan terdidik yang tumpul hendak kepekaan sosial, serta banyaknya anak muda yang beranggapan positivistik. Ketiga, hilangnya kebebasan berkomentar. Pemerintah Orde Baru yang dipandu oleh Soeharto mengedepankan motto 
"membangun manusia Indonesia seutuhnya serta Warga Indonesia" (https://attriolong.com).

Pada masa ini segala wujud pendidikan diperuntukan untuk penuhi hasrat penguasa, paling utama untuk pembangunan nasional. Siswa selaku peserta didik, dididik untuk jadi manusia" pekerja" yang nanti hendak berfungsi selaku perlengkapan penguasa dalam memastikan arah kebijakan negeri. Pendidikan bukan diperuntukan untuk mempertahankan eksistensi manusia, tetapi untuk mengeksploitasi intelektualitas mereka demi kepentingan penguasa pada saat itu. Yang lebih menyedihkan dari kebijakan pemerintahan Orde Baru terhadap pendidikan merupakan sistem doktrinisasi. Ialah suatu sistem yang memaksakan paham- paham pemerintahan Orde Baru supaya tertanam pada benak anak- anak. Apalagi dari semenjak sekolah dasar hingga pada tingkatan perguruan tinggi, diharuskan untuk menjajaki penetaran P4 yang berisi tentang hapalan butir-butir Pancasila (https://mygugum.woardpress.com).

Proses indoktrinisasi ini tidak hanya menanamkan paham- paham Orde Baru, namun juga sistem pendidikan masa Orde Baru yang menolak seluruh wujud budaya asing, baik itu yang memiliki nilai baik maupun memiliki nilai kurang baik. Paham Orde Baru yang membuat kita khawatir buat melangkah lebih maju. Dengan demikian, pendidikan pada masa Orde Baru bukan untuk tingkatkan taraf kehidupan rakyat, terlebih buat tingkatkan sumber energi manusia Indonesia, namun malah mengutamakan orientasi politik supaya seluruh rakyat itu senantiasa patuh pada tiap kebijakan pemerintah. Jika putusan pemerintah merupakan putusan yang adil dan tidak boleh dilanggar. Seperti itu doktrin Orde Baru pada sistem pendidikan kita. Indoktrinisasi pada masa kekuasaan Soeharto ditanamkan dari jenjang sekolah dasar hingga pada tingkatan pendidikan tinggi, pendidikan yang sepatutnya memiliki kebebasan dalam pemikiran. Pada masa itu, pendidikan difokuskan pada pengembangan militerisme yang militan sesuai dengan tuntutan kehidupan suasana perang dingin. Seluruhnya serba kaku serta berjalan dalam sistem yang otoriter (http://ranggambojoarea.blogspot.com).

\section{Kesimpulan}

Pendidikan menjadi hal yang paling penting untuk memajukan sebuah bangsa baik dari segi pembangunannya maupun secara pemerintahannya. Orde baru sering disebut sebagai orde pembangunan atau masa pembangunan dikarenakan pada saat itu 
pembangunan yang merata di daerah-daerah indonesia baik itu dipelosok wilayah indonesia tidak hanya itu pertumbuhan ekonomi juga pada saat itu cukup tinggi dan stabilitas nasional yang sehat dan dinamis. Pendidikan pada masa Orde Baru terdiri dari pendidikan pancasila, pendidikan agama dan pendidikan kewarganegaraan. Kurikulum pada masa Orde Baru terdiri dari kurikulum 1968 berisi kelompok pembinaan pancasila, pengetahuan dasar dan kecakapan khusus, penekananya hanya dalam segi intelektual lalu ada kurikulum 1975 ditekankan agar lebih efektif dan efisien berdasarkan MBO (management by objective) selanjutnya kurikulum 1984 berisi proccess skill approach model CBSA (cara belajar siswa aktif) atau SAL (student active learning), kurikulum 1994 berisi muatan nasional dan muatan lokal. Jenis pendidikan pada masa Orde Baru terdiri atas pendidikan formal, pendidikan informal dan pendidikan non formal. Jalur pendidikan pada masa Orde Baru terdapat jalur sekolah dan jalur luar sekolah. Jenjang pendidikan pada masa Orde Baru terdiri dari jenjang pra sekolah, jejang pendidikan dasar, jenjang pendidikan menengah dan jenjang pendidikan tinggi. Sistem pendidikan pada masa Orde Baru terdapat perubahan dari Orde Lama pada pelaksanaannya kegiatan kependidikan pada era ini difungsikan sebagai instrumen pembangunan ekonomi nasional, kebijakan pendidikan semuanya terpusat, pendidikan di selenggarakan dengan otorita kekuasaan administratif birokratis dan penyeragaman kurikulum juga diikuti dengan penyeragaman metode mengajar dan sistem evaluasi, yaitu Cara Belajar Siswa Aktif (CBSA). Pendidikan umum hendaknya tidak ditekankan hanya untuk kepentingan negara saja melainkan lebih memikirkan masa depan siswanya juga, pada Orde Baru ini pendidikan difokuskan untuk penguasa-penguasa saja seharusnya itu semua dihilangkan dan diminimalisirkan.

\section{Daftar Rujukan}

Abdullah, T. (2011). Indonesia dalam Arus Sejarah. Jakarta: Ichtiar Baru Van Haove.

Fadli, M. R., \& Kumalasari, D. (2019). Sistem Pendidikan Indonesia Pada Masa Orde Lama (Periode 1945-1966). Agastya: Jurnal Sejarah dan Pembelajarannya, 9(2), 157-171.

Helius, Sjamsudin. 2012. Metodologi Sejarah. Yogyakarta: Ombak.

https://attriolong.com. Diakses pada tanggal 11 maret 2021, pukul 16.35 WIB.

https://kelembagaan.ridtekdkti.go.id. Diakses pada tanggal 19 Maret 2021, pukul 07.45 WIB.

https://www.academia.edu. Diakses pada tanggal 19 Maret 2021 pukul 08.01WIB. 
Jailani, M. S., \& Muhammad, M. (2019). Kilas Balik Kebijakan Pendidikan Islam Indonesia pada Masa Orde Baru (1967-1997). INNOVATIO: Journal for Religious Innovation Studies, 19(1), 15-26.

Malla, H. A. B. (2011). Kajian Sosio Historis Tentang Politik Kebijakan Pendidikan Islam di Indonesia. Inspirasi, 1(14).

Marlina, M. (2016). Pengaruh Zeitgeist Terhadap Muatan Sejarah di Buku Teks Pelajaran Sejarah SMA Kurikulum 1975-2004. Indonesian Journal of History Education, 4(1).

Nizar, R. d. (2009). Filsafat Pendidikan: Telaah Sistem Pendidikan dan Pemikiran Para Tokohnya. Jakarta: Kalam Mulia.

Rangga, 2011. Sistem Pendidikan Indonesia Pada Masa Orde Baru 1968-1999. http://ranggambojoarea.blogspot.com/2011/06/sistem-pendidikan-indonesia-padamasa.html

Suharto, E. (2005). Membangun Masyarakyat Memberdayakan Rakyat. Bandung: Refika Aditama.

Susanto, Zuhdi, dkk. 2018. Sejarah Indonesia. Yogyakarta: Buku Sekolah Elektronik.

Syaharuddin dan Susanto, Heri. 2019. Sejarah Pendidikan Indonesia (Era Pra Kolonialisme Nusantara Sampai Reformasi). Banjarmasin: Program Studi Pendidikan Sejarah Fakultas Keguruan dan Ilmu Pendidikan Universitas Lambung Mangkurat.

Undang-Undang Republik Indonesia Nomor 20 Tahun 2003 tentang Sistem Pendidikan Nasional.

Yuningsih, H. (2015). Kebijakan Pendidikan Islam Masa Orde Baru. TARBIYA: Jurnal Ilmu Pendidikan Islam, 1(1), 175-194.

Yusuf, M. (2018). Pengantar Ilmu Pendidikan. Palopo: Lembaga Penerbit IAIN Palopo. 